\title{
ANALISIS UJI KADAR SENYAWA DAN UJI ANTIOKSIDAN EKSTRAK PROPOLIS COKLAT DARI LEBAH TRIGONA SP.
}

\section{Analysis Chemical composition and antioxidant activity of the crude brown propolis extracts from Trigona sp}

\author{
Novriza Sativa ${ }^{1}$ dan Rini Agustin ${ }^{2}$ \\ ${ }^{1}$ Dosen Program Studi Agroteknologi Fakultas Pertanian Universitas Garut \\ ${ }^{2}$ Mahasiswa Magister Biologi Laboratorium Fisologi, SITH, ITB \\ E-mail:nasativa2@gmail.com
}

\begin{abstract}
ABSTRAK
Propolis merupakan senyawa resin berasal dari berbagai tanaman yang dihasilkan oleh lebah. Penelitian ini dilakukan untuk menguji senyawa kadar senyawa yang terkandung dalam Propolis Coklat dari lebah Trigona sp. Pelarut yang digunakan dalam membuat ekstrak propolis adalah alkohol 70\%. Ekstrak Etanol Propolis (EEP) dimaserasi dan dihomogenkan menggunakan shaker selama 1 minggu. Propolis yang telah maserasi kemudian disaring dengan kertas saring dan diuapkan menggunakan rotavapour untuk menghilangkan pelarut. Ekstrak propolis kemudian di uji kadar senyawa yang terkandung di dalamnya dengan menggunakan Gas Chromatography-Mass Spectrometry (GC-MS). Sedangkan uji kadar antioksidan menggunakan uji 2,2-dyphenyl-1picrylhydrazyl (DPPH) yang menunjukkan bahwa propolis mampu menghambat radikal bebas.
\end{abstract}

Kata kunci: Propolis, GC-MS, DPPH, Ekstrak, Trigona $s p$

\begin{abstract}
Propolis is a resin compound derived from various plants produced by bees. The study was conducted to test the levels of compounds contained in brown Propolis from Trigona sp. Extract propolis solvent is used $70 \%$ alcohol. Propolis Ethanol Extract (EEP) was macerated and homogenized using a shaker for 1 week. The macerated propolis filtered with Whatmann paper and evaporated using a rotavapour to remove the solvent. Propolis extract compound tested by using Gas Chromatography-Mass Spectrometry $(G C-M S)$ while the antioxidant level used the 2,2-dyphenyl-1picrylhydrazyl (DPPH) test which showed that propolis was able to inhibit free radical scavenging.
\end{abstract}

Keywords : propolis, GC-MS, DPPH, Trigona sp, Extract 


\section{PENDAHULUAN}

Indonesia mempunyai keanekaragaman biodiversitas yang tinggi baik flora maupun faunanya sebagai sumber bahan alam obat-obatan. Propolis merupakan senyawa resin yang berasal dari berbagai macam tanaman dan dihasilkan oleh lebah. Propolis biasa digunakan oleh lebah untuk membuat, menutupi sekaligus melindungi celah pada sarang sehingga dikenal dengan sebutan "bee glue” (Bruno, 2005). Propolis atau disebut juga lem lebah, lengket dan berwarna kehitaman, diperoleh dari resin tanaman yang tercampur dengan secretory lebah berupa lilin. Propolis biasanya gunakan untuk mengkontruksi dan adaptasi sarangnya, serta sebagai antibakteri (Seidel, 2008) tetapi fungsi utamanya adalah untuk mengisi retakan yang terjadi di sarang lebah (Bankova dkk, 2002; Massaro dkk, 2013).

Propolis terdiri dari campuran senyawa resin, minyak esensial, dan lilin (wax), selain itu juga mengandung asam amino, terpenoid, asam benzoat, ester, mineral, etanol, vitamin A, vitamin B, E, senyawa fenolik, serta flavonoid (Bruno, 2005). Sejak beberapa abad yang lalu, propolis telah digunakan untuk bidang pengobatan. Propolis dikenal mempunyai kemampuan anti mikroba, antioksidan dan anti tumor. Sehingga propolis menjadi perhatian para peneliti untuk diketahui kandungan serta zat kimia yang potensial untuk pengobatan dan kosmetik (Lotfy, 2006). Selain itu propolis telah digunakan sejak lama pada zaman Mesir Kuno sebagai agen anti pembusukan untuk mengawetkan jasad manusia menjadi mumi (Sforcin, 2010).

Beberapa tahun belakangan di Indonesia sempat booming penggunaan propolis dengan informasi untuk mengobati berbagai penyakit. Tetapi komposisi propolis ditiap daerah baik di Indonesia maupun di luar biasanya berbeda tergantung dari sumber tanaman yang diperoleh oleh lebah. Adapun penelitian ini dilakukan untuk mengetahui komposisi apa saja yang terdapat di propolis beserta perkiraan kadarnya dan hasil uji dari antioksidan propolis coklat dari lebah Trigona $s p$. 


\section{METODE PENELITIAN}

\section{Lokasi dan Waktu Penelitian}

Penelitian ini dilaksanakan di Bandung, di Laboratorium Fisiologi SITH dan Gedung PAU ITB pada Januari-Maret 2017.

\section{Alat dan Bahan}

Alat yang digunakan pada penelitian ini adalah blender, gelas ukur, becker glass, erlenmeyer, shaker, aluminium foil, kertas saring Whatmann, plastik wrap, timbangan, rotavapour, GC MS dan DPPH. Adapun bahan yang digunakan adalah propolis coklat lebah Trigona sp. dari daerah Maribaya Bandung.

\section{Metodologi Penelitian}

Propolis diekstraksi menggunakan metode maserasi (Hasan dkk, 2013) dengan modifikasi. Propolis kasar (didapatkan dari daerah Maribaya Bandung, Jawa Barat) dihaluskan dengan menggunakan blender kemudian me-maserasi-nya dengan etanol 70\% lalu di-shaker selama satu minggu dan ekstrak etanolik propolis (EEP) sebelum dipanen. Proses maserasi diulang dengan waktu pemanenan filtrat $1 \times 24$, proses tersebut dilakukan sampai EEP berwarna tidak pekat. EEP kemudian disaring dengan kertas saring Whatmann yang kemudian diuapkan dengan rotavapour dan dikeringkan. Hasil ekstrasi propolis ini kemudian di analisis Gass Chromatography-Mass Spectrophotometry (GC-MS) untuk mengetahui komponen kimia di dalamnya dan dilakukan uji antioksidan dengan uji DPPH. Analisis GCMS dan Uji DPPH dilakukan di Laboratorium Politeknik Akademi Kimia Analis (AKA) Bogor, Jawa Barat 


\section{HASIL DAN PEMBAHASAN}

\section{Analisis GC-MS}

Pada penelitian ini, digunakan ekstrak etanol propolis yang diekstraksi dengan menggunakan pelarut etanol $70 \%$ untuk mendapatkan ekstrak yang mengandung fenol tinggi (Cunha, 2004). Hasil dari ekstraksi propolis dianalisis dengan GC-MS untuk mengetahui senyawa kimia yang terkandung didalamnya. Dari hasil GCMS diketahui terdapat 55 macam senyawa aktif dalam propolis.

Tabel Komponen Senyawa Kimia dari Propolis Hasil GCMS

\begin{tabular}{llc}
\hline No & \multicolumn{1}{c}{ Senyawa Kimia } & $\begin{array}{c}\text { Konsentrasi } \\
\text { Area (\%) }\end{array}$ \\
\hline 1 & Acetic acid & $\mathbf{6 . 3 2}$ \\
2 & N-(2-Hydroxyethyl)lactamide & 1.27 \\
3 & d-Threo-O-ethylthreonine & 1.34 \\
4 & Styrene & $\mathbf{0 . 6 6}$ \\
5 & 1,2-Propanediol diformate & 0.38 \\
6 & 1-Piperidinepropanol, .alpha.-cyclohexyl-.alpha.-phenyl- & 3.07 \\
7 & Butane, 1,2,4-trimethoxy- & 0.70 \\
8 & Acetic acid, trifluoro- & 0.43 \\
9 & Propanal, 3-methoxy- & 0.02 \\
10 & Propanamide, 2-hydroxy- & 1.00 \\
11 & Propanamide, 2-hydroxy- & 0.07 \\
12 & Propanamide, 2-hydroxy- & 1.46 \\
13 & Propanamide, 2-hydroxy- & 0.74 \\
14 & Hydroperoxide, 1-methylpentyl & 0.05 \\
15 & Propanamide, 2-hydroxy- & 0.81 \\
16 & Propanamide, 2-hydroxy- & 0.06 \\
17 & Butanoic acid, 2-oxo- & 0.04 \\
18 & Butanoic acid, 2-oxo- & 0.02 \\
19 & (3-Methyl-oxiran-2-yl)-methanol & 0.09 \\
20 & Hydroperoxide, 1-methylbutyl & 0.07 \\
21 & Ethanol, 2-bromo- & 0.23 \\
22 & Butanoic acid, 2-oxo- & 0.31 \\
23 & 1-(2-Hydroxyethoxy)-2-(vinylthio)ethane & 0.02 \\
24 & 3-(1-Ethoxyethoxy)-butyraldehyde & 0.14 \\
25 & (3-Methyl-oxiran-2-yl)-methanol 2030 1000194-22-9 47 & 0.08 \\
26 & Ethanol, 2-bromo- & 0.03 \\
27 & 3-Pentanone, dimethylhydrazone & 0.11 \\
28 & Imidodicarbonic acid, diethyl ester & 0.08 \\
29 & Thioguanine & 0.35 \\
30 & Methyl .beta.-d-galactopyranoside & 10.96 \\
31 & .alpha.-D-Glucopyranoside, .alpha.-D-glucopyranosyl & 0.03 \\
32 & Stevioside & 0.82 \\
33 & 7-Hydroxy-3-(1,1-dimethylprop-2 & 0.18 \\
& &
\end{tabular}


34 3-Cyclohexyl-4-morpholin-4-yl-py 0.38

35 Bicyclo[2.2.1]heptan-2-one 0.17

36 Dodecanoic acid $\quad 1.32$

37 Hexadecanoic acid, ethyl ester $\quad 4.77$

38 Bicyclo[2.2.1]heptan-2-one, 4,7,7-trimethyl-, $\quad \mathbf{0 . 1 7}$

39 semicarbazone $\quad 0.97$

40 Spiro-1-(cyclohex-2-ene)-2'-(5'-... 0.54

41 cis-7,cis-11-Hexadecadien-1-yl a...

42 Ethyl Oleate $\quad 0.28$

43 4-Allyl-5-furan-2-yl-2,4-dihydro-[1,2,4]triazole-3- $\quad 4.30$

44 thione6-Chloro-N-methyl-3-pyridazinamine 1.18

45 Methyl 3-(1-pyrrolo)thiophene-2-... $\quad 10.74$

46 8,11-Octadecadienoic acid, methy... $\quad 1.40$

47 2-Butenenitrile, 2-chloro-3-(4-m... $\quad 6.29$

48 2-Aminoacetic acid, N-diphenylme... $\quad 1.03$

49 3,6-Bis(N-dimethylamino)-9-ethyl... $\quad 4.10$

50 1-Propanone, 3-(2-hydroxyphenyl)... 2.06

51 Pyrido[2,3-d]pyrimidine, 4-phenyl- 6.54

52 5-Imidazolic amide, 4-amino-2-[4...

53 2-Ethylacridine $\quad 0.82$

54 2-Methyl-7-phenylindole 0.55

55 Dithiocarbonic acid, S-(2,3-diph...

5H-Cyclohepta[b]pyridine-3-carbo...

Komposisi dari propolis di atas, dari hasil GCMS berbeda dengan hasil uji senyawa pada penelitian sebelumnya yang dilakukan oleh Bankova dkk (2002) di Eropa. Dari penelitian tersebut diketahui propolis diantaranya mengandung pinocembrin, pinobanksin, adn 3-O-acetate, chrysinm galangin, prenyl esters dari caffeic dan ferulic acids. Selain itu penelitian lain yang berbeda signifikan adalah di Switzerland yang kaya akan phenolic glycerides dibandingkan dengan daerah Sicily yang sangat sedikit mengandung phenolic tetapi kaya akan diterpenic acids. Hal ini karena kondisi dari geografi, waktu, tanaman dan lokasi suatu daerah tempat ditemukannya sarang lebah yang mengandung propolis, mempunyai kadar komposisi senyawa, warna dan aroma yang berbeda (Lotfy, 2006).

Pada hasil uji GC-MS propolis diatas, komponen senyawa kimia yang telah teridentifikasi oleh hasil GC-MS dengan Quality diatas 70 adalah acetic acid dengan luas area konsentrasi sebesar 6.32\%. Senyawa kedua adalah Styrene sebanyak $0.66 \%$ yang merupakan senyawa yang dapat ditemukan di alam dari tanaman dan berbagai makanan seperti buah-buahan, sayuran, kacang kacangan, 
minuman dan daging-dagingan (Pubchem, 2018). Senyawa ini, termasuk golongan fenol jikadilihat dari strukturnya yang mempunyai cincin aromatik yang berikatan dengan gugus hidroksil.

Senyawa ketiga yang sudah dipastikan senyawa yang terdapat pada propolis coklat ini adalah Dodecanoic acid sebesar 1.32\%. Nama lainnya adalah lauric acid atau asam laurat yang merupakan turunan dari asam lemak yang termasuk kedalam trigliserida. Biasanya dapat ditemukan pada berbagai tanaman palm, pala, durian, melon, bunga labu dan lainnya (wikipedia, 2018). Senyawa Hexadecanoic acid, ethyl ester atau nama lainnya adalah ethyl palmitat merupakan senyawa ke empat yang diperkirakan konsentrasinya sebesar 4,77\% dalam propolis ini. Senyawa ini dapat ditemukan pada buah plum, anggur, jambu batu, melon, nanas, dan beberapa tumbuhan lain (Pubchem, 2018).

Senyawa selanjutnya adalah Bicyclo[2.2.1]heptan-2-one, 4,7,7-trimethyl-, semicarbazone dengan rumus formula $\mathrm{C}_{11} \mathrm{H}_{19} \mathrm{~N}_{3} \mathrm{O}$ mempunyai konsentrasi $0,17 \%$. Senyawa ini biasanya ditemukan pada hasilekstrak tanaman mint (Naidu dkk, 2012). Ethyl Oleate merupakan senyawa paling tinggi dengan konsentrasi mencapai 17.52\%. Merupakan senyawa fatty acid ethyl ester (FAEE) atau asamlemak dan diidentifikasi merupakan feromon utama yang biasanya ditemukan pada lebah, terbentuk setelah proses pencernaan yang mengandung etanol (wikipedia, 2018). Senyawa terakhir yang dapat dipastikan merupakan komponen dari propolis adalah 4-Allyl-5-furan-2-yl-2,4-dihydro-[1,2,4]triazole-3-thione. Senyawa dengan rumus molekul $\mathrm{C}_{9} \mathrm{H}_{9} \mathrm{~N}_{3} \mathrm{OS}$ mempunyai konsentrasi $0,28 \%$.

\section{Aktivitas Antioksidan}

Uji DPPH dilakukan untuk mengetahui kadar antioksidan dari propolis yang dibandingkan dengan antioksidan alami yaitu asam askorbat. Dari hasil uji antioksidan ini diketahui kemampuan dalam menangkap radikal bebas ketikapemberian konsentrasi yang terus dinaikkan. Berdasarkan nilai Inhibition Concentration IC50, ekstrak propolisini mampu menghambat radikal bebas sebanyak $50 \%$ jika konsentrasi yang diberikan adalah sebanyak 14,53 ppm. 
Sehingga diduga senyawa fenol dalam propolis berperan aktif dalam mengikat radikal bebas.

\section{KESIMPULAN}

Berdasarkan hasil penelitian ini, hasil ekstrak propolis diketahui mempunyai 55 komponen senyawa aktif, tetapi yang dapat dipastikan merupakan senyawa utama dari propolis hanya 7 macam senyawa berdasarkan hasil uji GC-MS. Sehingga diperlukan pengujian hasil analisis GC-MS di tempat lain sebagai perbandingan untuk memastikan nama-nama senyawa lain yang belum teridentifikasi secara pasti. Sedangkan hasil uji antioksidan diketahui propolis mempunyai aktivitas sebagai antioksidan yang tinggi sesuai dengan jumlah konsentrasinya.

\section{SARAN}

Penelitian masih memerlukan uji lanjutan dengan pengujian menggunakan GC-MS di tempat lain untuk memastikan komponen yang terkandung didalamnya. Hasil Quality dari best hits GC-MS diduga zat pengotor atau kemungkinan data base senyawanya terbatas. Sehingga diperlukan beberapa pengujian GC-MS dibeberap tempat untuk memastikan senyawa aktif pada propolis coklat ini.

\section{DAFTAR PUSTAKA}

Bankova, Vassya, Milena Popova, Stefan Bogdanov and Anna-Gloria Sabatini. 2002. Chemical Composition of European Propolis Expected and Unexpected Result. Z. Naturforsch. 57c, 530-533.

Bruno, Gene. 2005. Bee Pollen, Propolis, and Royal Jelly. Hutington College of Health Sciences, Hal. 1-3.

Cunha, Ildenize B. S., Alexandra C. H. F. Sawaya, Fabio M. Caetano, Mario T. Shimizu, Maria C. Marcucci, Flavia T. Drezza, Giovanna S. Povia and Patricia de O. Carvalho. 2004. Factors that Influence the Yield and composition of Brazilian Propolis Extracts. J. Braz. Chem. Soc. Vol 15, No. 6, 964-970.

Hasan, A.E.Z., D. Mangunwidjaja, T.C. Sunarti, O. Suparno, dan A. Setiono. 2013. Optimasi Ekstraksi Propolis Menggunakan Cara Maserari dengan Pelarut Etanol 70\% dan Pemanasan Gelombang Mikro serta Karakterisasinya 
sebagai Bahan Antikanker Payudara. Jurnal Teknologi Industri Pertanian 23(1) $13-21$.

Lotfy, Mahmoud. 2006. Biological Activity of Bee Propolis in Health and Disease. Asian Pacific Journa of Cancer Prevention. Vol 7, 22-31

Massaro, Flavia C , Peter Brooks, Helen M. Wallace, Vianne Nsengiyumva, Lorraine Narokai, Fraser D Russell. 2013. Effect of Australian Propolis from Stingless Bees (Tetragonula carbonaria) on Pre-Contracted Human and Porcine Isolated Arteries. PLOS ONE Volume 8 | Issue 11 | e8197

Seidel, Véronique, Elham Peyfoon, David G. Watson and James Fearnley. 2008. Comparative study of the antibacterial Activity od Propolis from Different Geographical and Climatic Zones. Phytotherapy Research 22, 1256-1263. DOI 10.1002/ptr.2480

Sforcin, J.M., V. Bankova. 2010. Propolis: Is there a potential for development of new drugs?. Journal of Etnopharmacology, 133, Hal. 253-260. 